\title{
Metric Analysis of Permanent and Deciduous Teeth from Bronze Age Tell Leilan, Syria
}

\author{
Scott Haddow and Nancy C. Lovell* \\ Department of Anthropology, University of Alberta, Edmonton, Alberta, Canada
}

\begin{abstract}
Between 1979 and 1989 the skeletal remains of 21 adults and 38 children, yielding 317 permanent and 134 deciduous teeth, were recovered at Tell Leilan, Syria, the site of a major urban center during the emergence of complex state society in northern Mesopotamia in the mid-third millennium BC. Tooth crown dimensions (faciolingual and mesiodistal diameters, total crown area, and molar crown area) are presented and the last two serve as the primary units of comparison for a diachronic interpretation of tooth size variation in the ancient Near East. Both permanent and deciduous dental data support the pattern of dental reduction since the Middle Paleolithic that has been documented for Asia
\end{abstract}

Analyses of ancient Near Eastern dentitions are sparsely represented in the literature, whether concerning pathology (e.g., Krogman, 1940; Carbonell, 1966), non-metric traits (e.g., Dahlberg, 1960; Rathbun, 1972), or metric variation (e.g., Macchiarelli, 1989; Rosenzweig and Zilberman, 1967, 1969). One reason for this may be that excavations of human remains at such classic sites as Kish (Mackay, 1925; Watelin and Langdon, 1934), and Ur (Wooley, 1934), were conducted in the early first half of the twentieth century, a time when studies of the teeth were not considered essential components of skeletal analysis. Unfortunately, although dental anthropological studies have become more common, the political climate of the Near East in recent decades has prevented research at many ancient Mesopotamian sites. As a consequence, some researchers have begun to explore the rich archaeological history of northern Mesopotamia, a region long ignored by archaeologists who, in the past, preferred to study agricultural origins and state emergence in the southern Iraqi floodplain. As a result of excavations conducted in northeastern Syria in the last quarter of the twentieth century, a new, albeit limited, set of archaeological human remains is available for analysis.

This paper presents the results of an odontometric analysis of human skeletal remains from the northern Mesopotamian site of Tell Leilan, Syria, and compares these results to odontometric data from other regions and time periods of the Near East in order to examine diachronic dental size variation. Documentation of dental reduction trends based on odontometric observation of archaeological populations has been achieved in a number of areas of the world for postPaleolithic Asia (Brace, 1978; Lukacs and Hemphill, and Europe. The total crown areas for the permanent and deciduous dental samples, $1189 \mathrm{~mm}^{2}$ and $497 \mathrm{~mm}^{2}$ respectively, place this archaeological population at the smaller end of the crown area scale for the Near East; smaller in size than nearby Paleolithic and Neolithic populations. Given the paucity of odontological data for this area, this study contributes to the odontometric history of Mesopotamia and as a summary compilation and comparison of previously conducted odontometric work as it relates to the phenomenon of dental reduction within the ancient Near East. Dental Anthropology 2003;16(3):73-80.

1991) and Upper Paleolithic-Mesolithic Europe (Frayer, 1977, 1978), but more work in regions and time periods previously unexamined by dental anthropologists will enable researchers to more accurately understand the evolutionary processes involved in hominid dental reduction, one of the most widely reported, and hotly debated trends in the study of human evolution (Brace, 1963, 1964, 1978; Brace et al., 1987, 1991; Calcagno, 1989; Gibson and Calcagno, 1989; Kieser, 1990; Macchiarelli and Bondioli, 1984). This study, then, is intended as a contribution to the odontometric history of Mesopotamia and as a summary compilation and comparison of previously conducted odontometric work as it relates to the phenomenon of dental reduction within the ancient Near East.

\section{MATERIALS AND METHODS}

Tell Leilan is located on the fertile Habur plains of northeastern Syria. Occupied from the mid-sixth millennium $B C$, the site became one of the three major urban centers of Subir during the emergence of complex state society in northern and southern Mesopotamia in the mid-third millennium BC (Weiss et al., 1993). During the Tell Leilan IIb period ( 2300-2200 BC), the imperial interests of the southern Mesopotamian ruler Sargon, and his successors, brought Tell Leilan and the rest of Subir under Akkadian domination (Gibbons, 1993; Weiss et al., 1993). At approximately 2200 BC, Tell Leilan was abandoned for some 300 years, due to severe

*Correspondence to: Dr. Nancy C. Lovell, Department of Anthropology, 13-15 Tory Building, University of Alberta, Edmonton, Alberta T6G 2H4, Canada.

E-mail: Nancy.Lovell@ualberta.ca. 
climate change that may have resulted from volcanic eruption and subsequent desertification of cultivable land in the region (Weiss et al., 1993). This climate change has been documented in a number of areas in the eastern Mediterranean (Amiran, 1986; Frumkin et al., 1991; Otterman and Starr, 1995; Raban and Galili, 1985), and has led some scholars to reevaluate previously held theories on the collapse of state-level societies in the ancient Near East during the late third millennium BC (Issar, 1995).

The skeletal remains of 21 adults and 38 children were recovered during five seasons of excavation at Tell Leilan between 1979 and 1989 (Weiss, 1985, 1986; Weiss et al., 1993), and are presently curated at the Department of Anthropology, University of Alberta. Preservation of the skeletal remains is poor, although the dentition, when present, is in excellent condition. However, only 317 teeth out of a potential 672 permanent teeth and only 134 of a possible 760 deciduous teeth were collected during excavation. Antemortem tooth loss probably contributed to the incomplete nature of the dental sample, as did difficulties in excavation; there are many neonatal and infant remains in which many of the deciduous teeth were either unformed or incompletely formed and hard to recover. Fortunately, one or more tooth crown dimensions (e.g., mesiodistal and/or faciolingual crown diameter) could be measured in $82 \%$ of the collected permanent teeth and $60 \%$ of the deciduous teeth. The remaining teeth could not be measured due to incomplete eruption, extreme occlusal wear, or postmortem crown breakage. The majority of the remains from Tell Leilan date to the urban period of third millennium occupation ( $\sim 2600$ to $\sim 2200 \mathrm{BC}$ ), although they range in date from the early third millennium BC to the early second millennium BC. Due to the small sample sizes and relatively homogenous cultural context, however, all the remains are treated here as a sample from a single population.

The senior author took tooth crown measurements with a Helios needle-point dial caliper, calibrated to $0.05 \mathrm{~mm}$. Measurements were rounded to $0.1 \mathrm{~mm}$. Two measurements, maximum faciolingual (FL) diameter ${ }^{1}$ and maximum mesiodistal (MD) diameter were taken for each tooth as described by Mayhall (2000). Intraobserver error was assessed by re-measurement of a randomly selected subset of $10 \%$ of the original sample, yielding a mean intraobserver measurement difference of 0.060 and a standard deviation of 0.22 ; such values are well within the ranges reported by other researchers for similar studies (Wolpoff, 1971a; Lukacs, 1985; Lukacs and Hemphill, 1991). Paired sample t-tests

\footnotetext{
${ }^{1 " F a c i o l i n g u a l " ~ i s ~ u s e d ~ h e r e ~ t o ~ e n c o m p a s s ~ b o t h ~ l a b i o l i n g u a l ~}$ measurements of the anterior teeth and buccolingual measurements of the posterior teeth.

${ }^{2}$ This precludes the utilization of the mean standard deviation for the Tell Leilan permanent dentition in comparative analysis of interpopulational dental asymmetry.
}

were used to assess FL and MD asymmetry of permanent right and left antimeres, although asymmetry was not evaluated for the deciduous sample because of its small size. Tabulation and statistical analysis of the data were completed using Excel (Microsoft Corporation, 1991) and Systat software (SYSTAT Inc., 1990-1992), respectively. The data are presented with the sexes pooled because the incomplete and fragmentary state of the skeletal remains rendered accurate assessment of sex for the Tell Leilan sample very difficult.

Crown area (CA) was calculated by multiplying the mesiodistal and faciolingual measurements for each tooth (Wolpoff, 1971b). Total crown area (TCA), the sum of mean cross-sectional crown areas for all upper and lower teeth on one side of the jaw, and molar crown area (MCA), the sum of the mean cross-sectional crown areas for upper and lower posterior teeth on one side of the jaw, serve as the primary units of comparison for diachronic interpretation of permanent tooth size variation in the ancient Near East. TCA and MCA values for the comparative samples were obtained either from published data or were calculated from published mean $\mathrm{MD}$ and FL crown diameters.

\section{RESULTS}

The mean differences between right and left measurements for each permanent tooth type were generated using a paired sample t-test. While there is a slight degree of directional asymmetry (with 11 of 16 teeth from the left side slightly larger, on average, than the right side), this difference is not statistically significant at alpha $=0.05$.

The standard deviation of mean differences between right and left antimeres provides another useful indicator of the extent of dental asymmetry (Smith et al., 1982). In contrast to the pattern that is usually observed (Lukacs and Hemphill, 1991), the Tell Leilan standard deviation does not display a trend of smaller to larger values when moving distally within a given tooth class. This is most likely caused by the small number of paired observations as well as by the large standard deviation of certain teeth (e.g., third molars). The mean standard deviation of FL and MD diameters for all teeth provides a general indication of asymmetry for the dentition as a whole (Lukacs and Hemphill, 1991); for the Tell Leilan permanent teeth, this value is 0.40 , somewhat higher than that observed by other researchers (e.g. 0.23 and 0.24, Lukacs and Hemphill, 1991)2, although Smith and co-workers (1982:283) have observed that standard deviations as large as 0.80 are not uncommon when samples of fewer than 100 individuals are used.

Crown diameters and areas are presented in Tables 1 and 2 for the left side of the dental arcade, and, because of the statistically insignificant nature of leftright antimeric differences, values from the right side have been substituted for missing left values in order to increase the number of observations for certain teeth and, 
TABLE 1. Mean crown diameters (in $\mathrm{mm}$ ) and mean crown areas (in $\mathrm{mm}^{2}$ ) of permanent left teeth from Tell Leilan ${ }^{1}$

\begin{tabular}{|c|c|c|c|c|c|c|c|c|c|c|c|c|c|c|c|c|}
\hline & \multicolumn{8}{|c|}{ MAXILLA } & \multicolumn{8}{|c|}{ MANDIBLE } \\
\hline & \multicolumn{3}{|c|}{$\begin{array}{l}\text { Faciolingual } \\
\text { Diameter }\end{array}$} & \multicolumn{3}{|c|}{$\begin{array}{c}\text { Mesiodistal } \\
\text { Diameter }\end{array}$} & \multicolumn{2}{|c|}{$\begin{array}{c}\text { Crown } \\
\text { Area }\end{array}$} & \multicolumn{3}{|c|}{$\begin{array}{l}\text { Faciolingual } \\
\text { Diameter }\end{array}$} & \multicolumn{3}{|c|}{$\begin{array}{l}\text { Mesiodistal } \\
\text { Diameter }\end{array}$} & \multicolumn{2}{|c|}{$\begin{array}{c}\text { Crown } \\
\text { Area }\end{array}$} \\
\hline & $\mathrm{n}$ & mean & $\mathrm{sd}$ & $\mathrm{n}$ & mean & $\mathrm{sd}$ & mean & $\mathrm{sd}$ & $\mathrm{n}$ & mean & sd & $\mathrm{n}$ & mean & $\mathrm{sd}$ & mean & $\mathrm{sd}$ \\
\hline & 12 & 7.38 & 0.37 & 12 & 8.58 & 0.64 & 63.36 & 6.35 & 6 & 6.05 & 0.21 & 7 & 5.16 & 0.76 & 29.79 & 3.46 \\
\hline 2 & 11 & 6.77 & 0.60 & 11 & 6.46 & 0.42 & 43.94 & & 10 & & 0.3 & 11 & 5.48 & 0.76 & 33.99 & 4.82 \\
\hline C & 10 & 8.63 & 0.46 & 10 & 7.30 & 0.45 & 64.02 & 5.1 & 9 & 7.92 & 0.53 & 1 & 6.71 & 0.37 & 52.60 & 3.83 \\
\hline P1 & 11 & 9.07 & 0.48 & 10 & 6.75 & 0.42 & 61.38 & 6.1 & 12 & 7.89 & 0.50 & 12 & 6.76 & 0.41 & 53.35 & 4.89 \\
\hline P2 & 11 & 9.07 & 0.66 & 11 & 6.53 & 0.43 & 59.43 & 7.8 & 12 & 8.0 & 0.81 & 12 & 7.03 & 0.62 & 58.69 & 10.46 \\
\hline M1 & 14 & 11.93 & 1.73 & 14 & 10.48 & 0.95 & 125.71 & 25. & 12 & 10.6 & 0.5 & 12 & 11. & 0.70 & 120.10 & 11.01 \\
\hline M2 & 11 & 10.85 & 1.07 & 10 & 9. & 1.10 & 103 & 19. & 11 & & 0. & 12 & & 0.80 & 115.57 & 11.01 \\
\hline M3 & 7 & 10.89 & 1.18 & 8 & 9.30 & 0.61 & 99.37 & 10.30 & 5 & 9.96 & 0.92 & 5 & 10.38 & 0.92 & 103.92 & 17.83 \\
\hline
\end{tabular}

${ }^{1}$ Since left-right antimeric differences are not statistically significant, values from the right side have been substituted for missing left values; n, number of observable teeth; sd, standard deviation

thus, the utility of the statistical results. Table 1 presents the mean FL and MD crown diameters and crown areas for the Tell Leilan permanent dentition, sexes pooled. All measurements are in millimeters $(\mathrm{mm})$ for crown diameters (FL and MD) and millimeters squared $\left(\mathrm{mm}^{2}\right)$ for crown areas (CA). Table 2 presents the mean FL and MD crown diameters and crown areas for both left and right antimeres in the deciduous dentition.

Numerous odontometric studies have utilized the TCA and/or the MCA for comparing tooth crown size variation (e.g., Brace, 1980; Lukacs, 1985; Brace et al., 1987), since crown areas most closely approximate the total functional occlusal size of the dentition (Wolpoff, 1971b). Thus, crown area is the trait upon which natural selection acts (Brace, 1980) making TCA and MCA, as single discrete values, highly useful for examining interpopulational variation in tooth size.

For the present study, the total and molar crown areas of the Tell Leilan permanent dental sample are compared with the total and molar crown areas from several archaeological populations in the Near East (Fig. 1), beginning in the Middle/Upper Paleolithic and ending in the Iron Age, as a rudimentary examination of tooth size reduction. Although it would be preferable to limit the diachronic comparison to sites that are specifically located within northern Mesopotamia, very few odontological studies have been conducted in the region. For this reason, crown area values for the nearest available archaeological populations in Iran, Iraq, Israel, and Turkey have been used instead.

Table 3 presents the data from sex-pooled samples for each archaeological population in the comparison.

TABLE 2. Mean crown diameters (in $\mathrm{mm}$ ) and crown areas (in $\mathrm{mm}^{2}$ ) for deciduous teeth from Tell Leilan

\begin{tabular}{|c|c|c|c|c|c|c|c|c|c|c|c|c|c|c|c|}
\hline \multirow{3}{*}{\multicolumn{2}{|c|}{ Side }} & \multicolumn{7}{|c|}{ MAXILLA } & \multirow[b]{3}{*}{$\mathrm{n}$} & & & \multicolumn{4}{|c|}{ MANDIBLE } \\
\hline & & \multicolumn{3}{|c|}{$\begin{array}{l}\text { Faciolingual } \\
\text { Diameter }\end{array}$} & \multicolumn{2}{|c|}{$\begin{array}{c}\text { Mesiodistal } \\
\text { Diameter }\end{array}$} & \multicolumn{2}{|c|}{$\begin{array}{l}\text { Crown } \\
\text { Area }\end{array}$} & & \multicolumn{2}{|c|}{$\begin{array}{c}\text { Faciolingual } \\
\text { Diameter }\end{array}$} & \multicolumn{2}{|c|}{$\begin{array}{l}\text { Mesiodistal } \\
\text { Diameter }\end{array}$} & \multicolumn{2}{|c|}{$\begin{array}{l}\text { Crown } \\
\text { Area }\end{array}$} \\
\hline & & $\mathrm{n}$ & mean & $\mathrm{sd}$ & & & & $\mathrm{sd}$ & & mean & & mean & sd & mean & $\mathrm{sd}$ \\
\hline \multirow[t]{2}{*}{ i1 } & $\mathrm{R}$ & 2 & 5.25 & 0.21 & 6.75 & 0.07 & 35.45 & 1.06 & 4 & 4.28 & 0.93 & 4.58 & 0.79 & 20.05 & 7.43 \\
\hline & $\mathrm{L}$ & 2 & 5.25 & 0.21 & 6.70 & 0.14 & 35.15 & 0.64 & 3 & 3.87 & 0.50 & 4.37 & 0.81 & 17.13 & 5.39 \\
\hline \multirow[t]{2}{*}{ i2 } & $\mathrm{R}$ & 2 & 5.15 & 0.21 & 5.80 & 0.00 & 29.85 & 1.20 & 3 & 4.70 & 0.61 & 5.23 & 0.72 & 24.73 & 5.66 \\
\hline & $\mathrm{L}$ & 2 & 4.80 & 0 & 5.45 & 0.21 & 26.15 & 1.06 & 3 & 4.60 & 0.56 & 5.67 & 1.25 & 26.53 & 8.98 \\
\hline \multirow[t]{2}{*}{ c } & $\mathrm{R}$ & 3 & 5.97 & 0.65 & 6.73 & 0.86 & 40.53 & 9.43 & 4 & 5.70 & 0.28 & 6.03 & 0.15 & 34.35 & 2.01 \\
\hline & $\mathrm{L}$ & 4 & 6.20 & 0.29 & 6.95 & 0.19 & 43.13 & 3.20 & 3 & 5.80 & 0.20 & 5.93 & 0.15 & 34.43 & 1.67 \\
\hline \multirow[t]{2}{*}{$\mathrm{m} 1$} & $\mathrm{R}$ & 4 & 8.75 & 0.17 & 7.55 & 0.58 & 60.05 & 8.57 & 4 & 7.20 & 0.27 & 8.75 & 0.31 & 63.08 & 4.65 \\
\hline & $\mathrm{L}$ & 4 & 8.73 & 0.11 & 7.53 & 0.68 & 65.83 & 8.14 & 4 & 7.15 & 0.47 & 8.68 & 0.33 & 62.13 & 5.94 \\
\hline \multirow[t]{2}{*}{$\mathrm{m} 2$} & $R$ & 4 & 9.85 & 0.66 & 9.53 & 0.17 & 93.75 & 4.72 & 4 & 8.73 & 0.15 & 10.53 & 0.29 & 91.80 & 1.55 \\
\hline & L & 4 & 10.00 & 0.39 & 9.73 & 0.33 & 98.28 & 5.19 & 4 & 8.88 & 0.26 & 10.55 & 0.29 & 93.60 & 2.67 \\
\hline
\end{tabular}




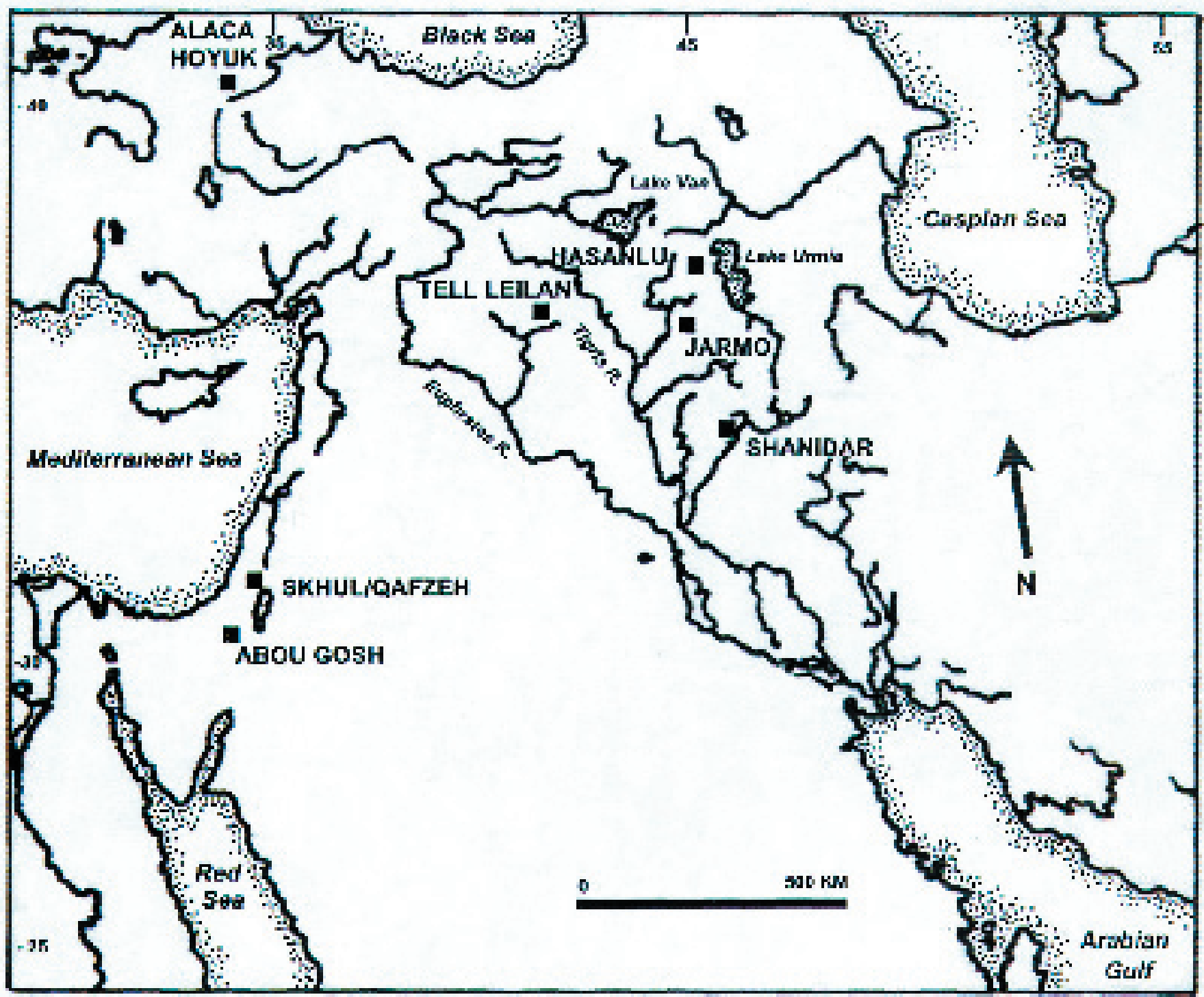

Fig. 1. Map of the Near East showing the sites used in the comparison of total and mean crown areas (Table 3). No sites are shown for the Natufian material, which Dahlberg described only as being from 'Mesolithic Palestine' (Dahlberg 1960:246).

With the exception of the TCA of the modern European sample, which is provided by Brace (1978), all TCA and MCA values were taken from the original MCAs given for each tooth class, or were calculated from published MD and FL crown diameters. In the case of the Neanderthal sample from Shanidar, crown areas for the anterior dentition could not be determined due to extreme occlusal wear (Trinkhaus, 1978), and thus the MCA serves as the primary comparative value. While the Tell Leilan crown diameters were recorded by measuring the maximum mesiodistal breadth for each tooth, it is not explicitly stated in a number of the odontological studies used for this comparison whether this same methodology was followed or whether the breadth between the mesial and distal contact facets of the molar teeth was measured in the manner of Hrdlička (1924) and others. The latter technique may give smaller crown diameters, and hence smaller summed crown areas. Values published elsewhere should thus be considered minimum estimates compared to the Leilan data presented here. This must be taken into consideration when looking at the comparative data, although the size of the difference is likely to be small, on the order of 1 to $2 \mathrm{~mm}$ per tooth, based on the personal experience of the authors.

As illustrated in Table 3, the overall trend in permanent tooth size variation is one of gradual reduction over time, beginning in the Middle/Upper Paleolithic with the Skhul/Qafzeh hominids and ending with the modern European population. The sample from Chalcolithic Alaca Höyük in Turkey does not follow this trend, however, having the smallest TCA, smaller even than the modern European sample. Many factors, including method of measurement and the biological affinities of the Alaca Höyük population may account for this difference. Despite this, the overall 
TABLE 3. Temporal variation in permanent tooth size among selected Near Eastern archaeological populations ${ }^{1}$

\begin{tabular}{llllll}
\hline $\begin{array}{l}\text { Sample } \\
\text { Name }\end{array}$ & $\begin{array}{c}\text { Site } \\
\text { Location }\end{array}$ & \multicolumn{1}{c}{$\begin{array}{c}\text { Cultural } \\
\text { Association }\end{array}$} & $\begin{array}{c}\text { TCA } \\
\left(\mathrm{mm}^{2}\right)\end{array}$ & $\begin{array}{c}\text { MCA } \\
\left(\mathrm{mm}^{2}\right)\end{array}$ & \multicolumn{1}{c}{ Source } \\
\hline Skhul & Israel & Middle Paleolithic & 1494 & - & Trinkaus, 1978 \\
Qafzeh & Israel & Middle Paleolithic & - & 780 & Vandermeersch, 1981 \\
Shanidar & Iraq & Upper Paleolithic & - & 773 & Trinkhaus, 1978 \\
Natufian & Palestine & Mesolithic & 1272 & 722 & Dahlberg, 1960 \\
Jarmo & Iraq & Neolithic & 1246 & 679 & Dahlberg, 1960 \\
Abou Gosh & Israel & Neolithic & 1240 & 685 & Aresnburg et al., 1978 \\
Tell Leilan & Syria & Bronze Age & 1189 & 668 & this study \\
Hasanlu & Iran & Iron Age & - & 605 & Rathbun, 1972 \\
Alaca Höyük & Turkey & Chalcolithic & 1161 & 643 & Senyürek, 1952 \\
European & various & Modern & 1138 & - & Brace, 1978 \\
\hline
\end{tabular}

${ }^{1}$ TCA, Total Crown Area; MCA, Molar Crown Area

trend is in accord with observations made by numerous researchers working in other regions of the world (e.g., Brace, 1978; Dahlberg, 1960, 1963; Lukacs and Hemphill, 1991; Sofaer, 1973).

If we examine the values from northern Mesopotamia specifically (i.e., Shanidar, Jarmo, and Tell Leilan), it can be seen that a reduction in molar crown area of about $100 \mathrm{~mm}^{2}$ has taken place in the time span between the Shanidar and Jarmo samples (approx. 55,000 yrs), giving an average MCA reduction rate of almost $0.002 \mathrm{~mm}^{2}$ per year. Subsequently, the MCA reduction between Jarmo and Tell Leilan is about $10 \mathrm{~mm}^{2}$, over a span of approximately 4,500 yrs, giving an average MCA reduction that is, also, about $0.002 \mathrm{~mm}^{2}$ per year. Although additional research is needed, this evidence suggests that the rate of dental reduction does not seem to be linked to subsistence strategy.

Consistent with their fit in the widely recognized trend to dental reduction, the Tell Leilan data support the contention that upper central incisors and the first molars are considered genetically stable. These teeth resist variation in tooth size to a greater extent than do the more distal, i.e., later developing, teeth within their respective tooth class (Dahlberg, 1963; Sofaer, 1973) so that the extent of tooth size variation increases distally. The MCA of the upper first molars exhibits a 3.2\% difference from Shanidar to Tell Leilan, as compared to a $28.8 \%$ change in the upper second molars. Similarly, there is a $2.6 \%$ change in lower first molar size from the Shanidar sample to the Tell Leilan sample, and a change of $15.5 \%$ in the lower second molars. ${ }^{3}$ Further, the change is $2.4 \%$ for upper first molars and $11.5 \%$ for upper second molars when comparing Tell Leilan and the earlier agricultural sample from Jarmo, and
$0 \%$ and $4.5 \%$ change for lower first and second molars, respectively.

By contrast to the case for permanent teeth, only a few studies have focused on the odontometry of the deciduous dentition (e.g., Koenigswald, 1967; Lukacs, 1981; Lukacs et al., 1983; Sciulli, 2001; Smith, 1978). Rarely have evolutionary trends in the deciduous dentition been documented, but Smith (1978), Lukacs and Hemphill (1991) and Sciulli (2001) have found that the rate of deciduous tooth size change is relatively stable within the past 5,000 to 10,000 years, roughly half that of permanent teeth (Lukacs and Hemphill, 1991). Table 4 compares the Tell Leilan deciduous TCA to Smith's (1978) data for several Near Eastern populations, from the Epipaleolithic to modern times. It can be seen that, as with the permanent dentition, a distinct reduction trend can be observed over time.

\section{DISCUSSION}

Many scholars have debated the mechanisms of dental reduction, but most agree that an overall reduction in tooth crown size should be observed in populations as they move from nomadic hunting and gathering subsistence modes to more sedentary agricultural modes (e.g., Dahlberg, 1963; Sofaer, 1973). Indeed, studies have shown that the rate and extent of human dental reduction was at its most profound after the Pleistocene, precisely the time period during which the transition in subsistence modes occurred (Calcagno, 1989; Macchiarelli and Bondioli, 1986; Reddy, 1992).

${ }^{3}$ Crown areas were not available for the Shanidar anterior teeth and thus cannot be compared with values for the Tell Leilan sample 
TABLE 4. Temporal variation in deciduous tooth size of selected Near Eastern populations ${ }^{1}$

\begin{tabular}{lrcrcl}
\hline $\begin{array}{c}\text { Cultural } \\
\text { Association }\end{array}$ & $\mathrm{n}$ & $\begin{array}{c}\text { TCA } \\
\left(\mathrm{mm}^{2}\right)\end{array}$ & $\mathrm{n}$ & $\begin{array}{l}\text { MCA } \\
\left(\mathrm{mm}^{2}\right)\end{array}$ & Source \\
\hline Epipaleolithic & 139 & 550 & 50 & 333 & Smith, 1978 \\
Neolithic & 130 & 504 & 61 & 318 & Smith, 1978 \\
Chalcolithic & 202 & 459 & 88 & 286 & Smith, 1978 \\
Middle Bronze Age II & - & - & 130 & 293 & Smith, 1978 \\
Bronze Age (Tell Leilan) & 35 & 497 & 16 & 319 & this study \\
Iron Age & 509 & 474 & - & - & Smith, 1978 \\
Modern & 212 & 454 & - & - & Smith, 1978 \\
\hline
\end{tabular}

${ }^{1}$ TCA, Total Crown Area; MCA, Molar Crown Area

Although reduction in the size of the dentition occurred during the Pleistocene, this reduction may be related to an overall reduction in body size or robusticity, especially in the masticatory apparatus and facial skeleton in general (Macchiarelli and Bondioli, 1986; Brace et al., 1991). Alternatively, selective pressures that favored larger or smaller teeth, depending on specific environmental conditions affecting dental health, may act as the primary mechanism of reduction (Calcagno, 1989; Calcagno and Gibson, 1991). Such conditions may have included dietary toughness and/or abrasiveness. Early cultural advancements such as food preparation techniques (e.g., the use of fire to cook raw plant and animal foods), pottery, increasingly sophisticated tools, and changes in diet also may have played a role in selecting for smaller tooth sizes.

Given the paucity of odontological data for this area, however, it is not within the scope of this paper to determine the exact mechanisms of dental reduction for the region of Northern Mesopotamia. Presently, there are no sources of modern Near Eastern odontometric studies suitable for comparative purposes. Rosensweig and Zilberman's (1969) odontometric analysis of modern Bedouin in Israel did not include the third molars. Thus, the TCA for a modern European population (Brace, 1978) is included in Table 3 as an illustration of the extent of dental reduction since the Middle Paleolithic. Studies of modern human populations have shown that the smallest tooth crown dimensions today are observable in Europeans and certain Asian populations (Dahlberg, 1963; Lukacs, 1985). Some researchers have argued that this is because these regions were some of the earliest sites of sedentary agricultural development, and consequently have had the longest amount of time for dental reduction to occur (Brace, 1978; Reddy, 1992). Because the region of Mesopotamia is also one of the earliest sites of agricultural development, the same small tooth dimensions should be expected for modern Near Eastern populations. However, in all cases, extenuating factors such as genetic makeup, the migration of peoples and genetic drift will also play a role, the extent of which may be hard to determine at this time. What needs further investigation is that the rate of dental reduction appears to have remained constant through a transition from Upper Paleolithic hunting-foraging through the origins of food production and into the metal ages (data in Table 3). This is, in fact, contrary to predictions of tooth size according to modes of subsistence, and may lend credence to explanations based on overall decreases in skeletal robusticity, which were more pronounced between the Upper Paleolithic and the Neolithic than between the Neolithic and the metal Ages.

\section{CONCLUSIONS}

Results reported here of the metric analysis of the permanent and deciduous dentition of the northern Mesopotamian Bronze Age site of Tell Leilan, when compared with odontometric data from varying periods within the Near East, are consistent with the pattern of hominid dental size reduction observed worldwide since the Middle Paleolithic. The total crown areas (TCA) for the Tell Leilan permanent and deciduous dental samples, $1189 \mathrm{~mm}^{2}$ and $497 \mathrm{~mm}^{2}$, respectively, place this archaeological population at the smaller end of the crown area scale for the Near East; smaller in size than nearby Paleolithic and Neolithic populations, and slightly larger than more recent populations and the modern samples. The rate of reduction in hominid dentition has varied both spatially and temporally over the course of human evolution (e.g., Calcagno, 1989; Macchiarelli and Bondioli, 1986; Reddy, 1992), and factors such as genetic drift and the blending of geographically diverse populations over time often obscure or complicate our understanding of human dental reduction, especially in the post-Paleolithic. It is hoped that larger dental samples from a wider variety of sites in ancient Mesopotamia will eventually allow for a more detailed documentation of metric dental trends in this region and time period of the Near East.

\section{ACKNOWLEDGEMENTS}

We thank Harvey Weiss for making available the skeletal remains from Tell Leilan. Financial support from the University of Alberta (Faculty of Arts SAS 
Fund, and the Central Research Fund) and the Social Sciences and Humanities Research Council of Canada (Standard Research Grant \#410-95-0254) to Nancy Lovell, and from the University of Alberta (Faculty of Arts and Faculty of Graduate Studies and Research) to Scott Haddow, is gratefully acknowledged.

\section{LITERATURE CITED}

Amiran R. 1986. The fall of the early Bronze Age II city of Arad. Israel Explor J 36:74-76.

Angel JL. 1968. Appendix: human remains at Karatas. Am J Archaeol 72:260-263.

Angel JL, Bisel SC. 1986. Health and stress in an early Bronze Age population. In: Canby JV, Porada E, Ridgway BS, Stech T, editors. Ancient Anatolia. Madison: University of Wisconsin Press, p 12-30.

Arensburg B, Smith P, Yakar R. 1978. The human remains from Abou Gosh. In: Lechevallier M, editor: Abou Gosh et Beisamoun: Deux Gisements $\mathrm{du}$ VII Millenaire Avant 1’Ere Chretienne en Israel. Memoires et Travaux du Centre de Recherches Prehistorique Francais de Jerusalem, No. 2, p 95104.

Brace CL. 1963. Structural reduction in evolution. Am Nat 97:46-59.

Brace CL. 1964. The probable mutation effect. Am Nat 98:453-455.

Brace CL. 1978. Tooth reduction in the Orient. Asian Perspect 19:203-252.

Brace CL. 1980. Australian tooth size clines and the death of a stereotype. Curr Anthropol 21:141-164.

Brace CL, Rosenberg KR, and Hunt KD. 1987. Gradual change in human tooth size in the Late Pleistocene and Post-Pleistocene. Evol 41:705-720.

Brace CL, Smith SL, Hunt KD. 1991. What big teeth you had grandma! human tooth size, past and present. In: Kelly MA, Larsen CS, editors. Advances in dental anthropology. New York: Wiley-Liss, p 33-57.

Buikstra J, Ubelaker DH. 1994. Dental data collection II: dental morphology and measurements of the secondary dentition. In: Buikstra J, Ubelaker $\mathrm{DH}$, editors. Standards for data collection from human remains. Fayetteville, Ark: Arkansas Archaeological Survey, p 60-63.

Buxton LHD, and Rice DT. 1931. Report on the human remains found at Kish. J R Anthropol Inst 61:57-119.

Calcagno JM. 1989. Mechanisms of human dental reduction: a case study from modern Nubia. Lawrence: University of Kansas Publications in Anthropology, no. 18.

Calcagno JM, Gibson KR. 1991 Selective compromise: evolutionary trends and mechanisms in Hominid tooth size. In: Kelly MA, Larsen CS, editors. Advances in dental anthropology. New York: WileyLiss, p 59-76.

Cappieri M. 1969. The Mediterranean race in Asia before the Iron Age. Occasional Paper No. 8. Miami: Field
Research Projects.

Cappieri M. 1970. The Mesopotamians of the Chalcolithic and Bronze Ages. Occasional Paper No.12. Miami: Field Research Projects.

Cappieri M. 1972. Genotypical and phenotypical homogeneity of the ancient population of Anatolia. Miami: Field Research Projects.

Cappieri M. 1973. The Iranians of the Copper/Bronze Age. Miami: Field Research Projects.

Carbonell VM. 1966. The paleodental pathology of ancient Mesopotamians. J Dent Res 45: 413.

Dahlberg AA. 1960. The dentition of the first agriculturalists (Jarmo, Iraq). Am J Phys Anthropol 18:243-256.

Dahlberg AA. 1963. Dental evolution and culture. Hum Biol 35:237-249.

Frayer DW. 1977. Metric dental changes in the European Upper Paleolithic and Mesolithic. Am J Phys Anthropol 46:109-120.

Frayer DW. 1978. Evolution of the dentition in Upper Paleolithic and Mesolithic Europe. University of Kansas Publications in Anthropology, no. 10.

Frumkin A, Magaritz M, Carmi I, Zak I. 1991. The holocene climatic record of the salt caves of Mount Sedom, Israel. The Holocene 1:191-200.

Gibbons A. 1993. How the Akkadian empire was hung out to dry. Science 261:985.

Gibson KR, Calcagno JM. 1989. A critique of the "increasing population density effect." Hum Evol 4: 515-523.

Greene DL. 1984 Fluctuating dental asymmetry and measurement error. Am J Phys Anthropol 65:283289.

Hanihara T. 1998. Metric and nonmetric dental variations of major human populations. In: Lukacs JR, editor. Human dental development, morphology, and pathology: a tribute to Albert A. Dahlberg. Eugene: University of Oregon Press, p 173-200.

Hillson SW. 1996. Dental anthropology. Cambridge: Cambridge University Press.

Hrdlička A. 1924. New data on the teeth of early man and certain fossil European apes. Am J Phys Anthropol 7:109-132.

Issar AS. 1995. Climatic change and the history of the Middle East. Am Sci 83:350-355.

Kieser JA. 1990. Human adult odontometrics. Cambridge: Cambridge University Press.

von Koenigswald GHR. 1967. Evolutionary trends in the deciduous molars of the Hominidae. J Dent Res 46:779-786.

Krogman WM. 1940. The skeletal and dental pathology of an early Iranian site. Bull Hist Med 8:28-48.

Lukacs JR. 1985. Tooth size variation in prehistoric India. Am Anthropol 87:811-825.

Lukacs JR, Hemphill BE. 1991. The dental anthropology of prehistoric Baluchistan: a morphometric approach to the peopling of south Asia. In: Kelly MA, Larsen 
CS, editors. Advances in dental anthropology. New York: Wiley-Liss, p 77-119.

Lukacs JR, Joshi MR, Makhija PG. 1983. Crown dimensions of deciduous teeth of prehistoric and living populations of western India. Am J Phys Anthropol 61:383-387.

Macchiarelli R. 1989. Prehistoric "fish-eaters" along the Eastern Arabian coasts: dental variation, morphology, and oral health in the Ra's al-Hamra community (Qurum, Sultanate of Oman, 5th-4th millennia BC). Am J Phys Anthropol 78:575-594.

Macchiarelli R, Bondioli L. 1984. Time and dental structure reduction in man: a reassessment of mechanisms. Antropol Contemp 7:102.

Macchiarelli R, Bondioli L. 1986. Post-Pleistocene reductions in human dental structure: a reappraisal in terms of increasing population density. Hum Evol 1:405-418.

Mackay E. 1925. Report on the Excavations of the 'A' Cemetery at Kish, Mesopotamia: Part I. Field Museum of Natural History, Anthropology Memoirs Vol.1(1). Laufer B, editor. Chicago: Field Museum of Natural History.

Mayhall JT. 2000. Dental morphology: techniques and strategies. In: Katzenberg MA, Saunders SR, editors. Biological anthropology of the human skeleton. New York: Wiley-Liss, p 103-134.

Otterman J, Starr DO. 1995. Alternative regimes of surface and climate conditions in sandy arid regions: possible relevance to Mesopotamian drought 22001900 BC. J Arid Environ 31:127-135.

Raban A, Galili E. 1985. Recent maritime archaeological research in Israel: a preliminary report. Inter J Naut Archaeol Underwater Explor 14:332-349.

Rathbun TA. 1972. A study of the physical characteristics of the ancient inhabitants of Hasanlu, Iran. Miami: Field Research Projects.

Rathbun TA. 1982. Morphological affinities and demography of Metal-Age southwest Asian populations. Am J Phys Anthropol 59:47-60.

Rathbun TA. 1984. Metric and discrete trait variation among southwest Asian populations. Spectra Anthropol Prog 6:23-50.

Reddy VR. 1992. Trends in hominid dental evolution: an appraisal. In: Smith P, Tchernov E, editors. Structure, function and evolution of teeth. London: Freund Publishers, p 539-551.

Rosenzweig KA, Zilberman Y. 1967. Dental morphology of Jews from Yemen and Cochin. Am J Phys Anthropol 26:15-22.

Rosenzweig KA, Zilberman Y. 1969. Dentition of
Bedouin in Israel. Am J Phys Anthropol 31:199-204.

Senyürek MS. 1952. A study of the dentition of the ancient inhabitants of Alaca Höyük. Belleten 16: 153-232.

Senyürek MS. 1954. A note on the skulls of Chalcolithic age from Yümüktepe. Belleten X18:1-25.

Smith BH, Garn SM, Cole PE. 1982. Problems of sampling and inference in the study of fluctuating dental asymmetry. Am J Phys Anthropol 58:281-289.

Smith P. 1978. Evolutionary changes in the deciduous dentition of Near Eastern populations. J Hum Evol 7:401-408.

Smith P. 1989. The skeletal biology and paleopathology of early Bronze Age populations in the Levant. In: de Miroschedji P, editor. L'urbanisation de la Palestine`a l'Âge du Bronze Ancien: Bilan et Perspectives de Recherches Actuelles. Actes du Colloque d'Emmaüs (20-24 octobre 1986). BAR Inter Ser 527 (ii), p 297313.

Sofaer JA. 1973. A model relating developmental interaction and differential evolutionary reduction of tooth size. Evol 27:427-434.

Trinkhaus E. 1978. Dental remains from the Shanidar adult Neanderthals. J Hum Evol 7:369-382.

Vandermeersch B. 1981. Les Hommes Fossiles de Qafzeh (Israel). Paris: Centre National de Recherche Scientifique.

Watelin L, Langdon S. 1934. Excavations at Kish: the Herbert Weld and Field Museum of Natural History Expedition to Mesopotamia. Vol. 4 (1925-1930). Paris: Librairie Orientaliste Paul Geuthner.

Weiss H. 1985. Tell Leilan on the Habur Plains of Syria. Bib Archaeol March:6-34.

Weiss H. 1986. Introduction: the origins of cities in dry-farming Syria and Mesopotamia in the third millennium BC. In: Weiss $\mathrm{H}$, editor. The origins of cities in dry-farming Syria and Mesopotamia in third millennium BC. Guildford: Four Quarters, p 1-6.

Weiss H, Courty MA, Wetterstrom W, Guichard F, Senior L, Meadow R, Curnow A. 1993. The genesis and collapse of third millennium north Mesopotamian civilization. Science 261:995-1004.

Wolpoff MH. 1971a. Metric trends in hominid dental evolution. Cleveland: Case Western Reserve University, Studies in Anthropology, no. 2.

Wolpoff MH. 1971b. A functional measure of tooth size. Southwest J Anthropol 27:279-286.

Wooley CL. 1934. Ur Excavations Vol. II: the Royal Cemetery: a Report on the Predynastic and Sargonid Graves Excavated Between 1926 and 1931. New York: Trustees of the Two Museums; Carnegie Corp. 